КУХАРЧИК О.Г. aспірант

Інститут проблем ринку та економіко- екологічних досліджень НАНУ Франиузький бульвар, 29, м. Одеса, Украйна, 65044

E-mail:v_g_k_@ukr.net

\title{
СТВОРЕННЯ МУЛЬТИМОДАЛЬНОГО КЛАСТЕРУ
}

В роботі розглянуті перспективи розвитку транспортно-виробничих об'єднань в системі морегосподарського комплексу України. Дано визначення кластеру, проаналізовані його види. Запропоновано створити мультимодальний кластер в Одеському регіоні. Морські торговельні порти стають иентрами інтенсифікації обробки транспортних і вантажних потоків.

Ключові слова: мультимодальні перевезення; море господарський комплекс; мультимодальний кластер

KUKHARCHYK A.G.

graduate student

Institute Of Market Problems And Economic\&Ecological Research of the

National Academy Of Sciences Of Ukraine

Frantsuzskiy Boulevard, 29, Odessa, Ukraine

E-mail:v_g_k_@ukr.net

\section{MULTIMODAL CLUSTER CREATION}

The prospects of the transport development and production associations in the sea-economic system complex of Ukraine are considered in the paper. The definition of a cluster is given, its types are analyzed. It is proposed to create a multimodal cluster in the Odessa region. Maritime trade ports become centers for the intensification of transport and freight flows. The development of interaction forms comes from the simplest port and industrial zones through their association in port-industrial units based on the general infrastructure, the creation of port-industrial complexes and the formation of transport and industrial complexes, representing an informal association of transport and industrial enterprises. As well as related organizations located in a certain territory and operating on the principles of commonality of interests. A higher level of interaction between enterprises, organizations and institutions in the system of a sea-economy complex should be the creation of multimodal clusters in the marine regions of the country, involving the involvement of educational institutions, research institutes, banks, insurance companies and other companies in the sphere of interaction, which will create an atmosphere of trust between power and business, improve the competitive environment, provide productivity growth both to industrial enterprises and to port activity and related activities.

Keywords: Multimodal transportation, sea economic complex, multimodal cluster

Постановка проблеми та їі зв'язок з важливими науковими та практичними завданнями. Проаналізувати існуючі етапи розвитку транспортно-виробничих об'єднань. Обгрунтувати групи факторів привабливості для вантажовласників. Уточнити термінологію при вивченні поняття кластер в економіці. Охарактеризувати основні зони взаємодії в системі портово-промислової зони.

Аналіз останніх публікацій по проблемі. Особливості мультимодальних перевезень були розглянуті в працях Котлубая О.М., Лимонова Е.Л., Плужникова К.І., Чунтомової Ю.А., Скарідової А.С., Цветова Ю.М., Чекаловца В.Г. та інших авторів [1,2,3]. Концепція кластерів розглядалась в роботі Войнаренко М.П. як шлях до відродження виробництва на регіональному рівні, в роботі Крижановського С.В. як формування морського кластеру, та в працях інших авторів.[4,5,6].

Виділення невирішених раніше частин загальної проблеми. Для визначення потенційно можливих схем розвитку мультимодальних перевезень необхідно встановити причинно-наслідкові зв'язки і фактори вибору нових підходів до оптимальної системі управління. Концепція кластерів в цьому випадку є новим способом бачення національної економіки. Значення кластера для економіки України величезне, що обумовлює необхідність вивчення і розробки механізму функціонування цієї нової організаційної форми господарювання.

До недавнього часу вважалося, що рівень конкурентоспроможності держави та ії регіонів в основному залежить від внутрішніх процесів, що відбуваються в ньому, від стратегії його розвитку і

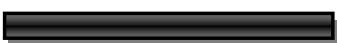

132

Економічні інновації

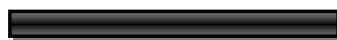

Випуск №63 
економічної політики. Глобалізація дала суб'єктам господарювання можливість отримувати капітал, товари і технології звідки завгодно і розміщувати виробництво там, де це виявляється більш ефективним. [7-10]. кластеру.

Формулювання цілей дослідження. Показати переваги створення мультимодального

Виклад основних результатів та їх обгрунтування.

(англ. cluster) — група однакових або

(чогось однорідного). Кластер (в економіці) - сконцентрована на деякій території група взаємопов'язаних організацій (компаній, корпорацій, університетів, банків та ін.): Постачальників продукції, комплектуючих і спеціалізованих послуг; інфраструктури; науково-дослідних інститутів; вузів та інших організацій, які взаємодоповнюють один одного і підсилюють конкурентні переваги окремих компаній і кластера в цілому. Кластер має властивості взаємної конкуренції його учасників, кооперації його учасників, формування унікальних компетенцій регіону, формуванням концентрації підприємств і організацій на певній території.

При розвитку мультимодальних транспортних технологій саме морські торговельні порти стають центрами інтенсифікації обробки транспортних і вантажних потоків. Вони грають роль вузлових або опорних точок міжнародних транспортних коридорів та інших форм співпраці різних підрозділів виробничої інфраструктури. При виборі перевізника і маршруту слідування на перше місце виходять критерії швидкості, часу, мінімуму витрат і оптимуму надійності.

Зараз як перед портами так і перед підприємствами стоять завдання вибрати унікальну позицію для гарантування стійкої конкурентної переваги в перспективі.

Раніше вважалося, що основною передумовою для завоювання ринкових позицій $є$ можливість зниження виробничих витрат з відповідною оптимізацією тарифної політики з боку держави.

Однак труднощі, з якими стикаються як морські торговельні порти так і підприємства далеко не завжди можуть бути компенсовані лише зниженням рівня цін на портову продукцію. Вкрай необхідним $є$ постійне зростання номенклатури портових робіт, забезпечення їх високої якості в поєднанні з індивідуальним підходом до кожного клієнта порту.

Портова продукція, як і будь-яка інша, має комплексом властивостей, що визначають ії придатність до використання в конкретних умовах. Для того щоб об'єктивно оцінити ринкові перспективи своєї нової продукції або послуг, порт повинен використовувати ті самі критерії, що і споживач. Тільки тоді можна очікувати, що оцінка, дана портової продукції або послуги самим портом, співпаде $з$ думкою клієнта. Необхідно постійне уточнення переліку вимог до портової продукції та послугам і пов'язаної з ними діяльністю, істотних з погляду споживача. Порт повинен точно оцінити і саму принципову можливість розширення спектру надаваних послуг.

Підвищення ролі комплексності в господарському та інвестиційному процесах, збільшення товарної маси, що знаходиться в процесі доставки в місця споживання, визначають основну вимогу до розвитку підприємств портової діяльності. Останнє виражається в спеціалізації перевантажувальних комплексів на базі диверсифікації портової продукції, зростанні кількості наданих послуг в одному місці та вдосконалення організації процесу доставки товару від споживача зі зміною його властивостей.

Кінцевим результатом є розширення сфери обслуговування транспортних і вантажних потоків на території морського торгового порту.

До групи факторів привабливості для вантажовласника слід віднести:

1) підвищення рівня збереження товарів в процесі його доставки від виробника до споживача. Концентрація промисловості на портової території тягне за собою скорочення відстані транспортування вантажу, що обумовлює зниження рівня втрат і пошкоджень за час переміщення вантажу від місця виробництва до порту;

2) зниження собівартості заробітчанства товарів за рахунок масштабів виробництва, причиною чого $є$ акумулювання аналогічних вантажів різних вантажовласників у портовій промисловій зоні, що забезпечує мінімізацію як виробничих, так і невиробничих витрат на одиницю продукції;

3) поліпшення споживчих властивостей товару, результатом чого може бути зростання продажної ціни. «Наприклад, сортування товарів відповідно до вимог європейських стандартів, підвищує продажну ціну товару в декілько разів по відношенню до первісної вартості необробленої сировини»;

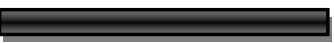

2017
Економічні інновації

Випуск №63

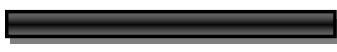

133 
4) скорочення транспортних витрат за рахунок зниження ваги вантажу внаслідок очищення, сортування і т.д. У підсумку до перевезення пред'являється меншу кількість вантажу.

Фактори привабливості для морського торгового порту полягають в наступному:

1) забезпечення стабільного вантажопотоку з боку вантажовласників, які крім переміщення вантажу потребують доведенні його до остаточного, продажного вигляду;

2) залучення суміжних вантажопотоків. В інтересах вантажовласників, які користуються послугою підробітку на припортової території, перевантажувати і інші вантажі в даному порту, а не налагоджувати контакти з іншими портами.

Третя група включає наступні фактори привабливості для регіону:

1) зниження соціальної напруженості шляхом створення нових робочих місць. Збільшення масштабів виробничої діяльності в порту спричинить за собою збільшення потреби в робочій силі, результатом чого буде зростання зайнятості населення, збільшення купівельної спроможності, зниження рівня безробіття і т.д.;

2) збільшення відрахувань до бюджетів різних рівнів. Результатом розширення номенклатури виконуваних робіт буде створення нових суб'єктів господарювання, які в процесі функціонування здійснюватимуть відрахування коштів у вигляді різних податків і платежів;

3) зростання інвестиційної привабливості. Зацікавленість вантажовласників у зростанні інтенсивності та підвищенні якості продукції та робіт порту, стимулює їх спрямовувати кошти на розвиток інфраструктури порту;

4) активізація малого та середнього бізнесу. Активізація роботи порту тягне за собою зростання ділової активності як в портовій зоні, так і в усьому морському регіоні внаслідок розвитку супутніх і суміжних секторів господарювання, наприклад, сервісної діяльності морського транспорту, яка складається в основному з представників малого та великого бізнесу.

У той же час виконання цього завдання вимагає чіткої і злагодженої роботи всіх об'єктів, що функціонують на портової території. Структура портового господарства, з одного боку, визначається його багатофункціональністю, а 3 іншого, необхідністю інтенсивної обробки транспортних i вантажних потоків. У свою чергу сьогодні існує ряд альтернативних підходів до управління господарською діяльністю та оптимізації виробничої структури торгового порту.

Таким чином, вдосконалення системи управління підприємством та портовим господарством, підвищення ролі комплексності в процесі переміщення вантажу обумовлюють посилення впливу взаємодії порту, виробничих підприємств та інших учасників процесу доставки товару. Завдяки введенню в експлуатацію нових перевантажувальних комплексів, технічного переозброєння діючих терміналів, а також активізації діяльності промисловості, на території порту забезпечується збереження, а іноді і поліпшення позиції підприємств портової діяльності на ринку транспортних послуг.

Зазначене вище, а також націленість на зростання конкурентної стійкості підприємств портової діяльності обумовлюють пошук нових форм їх співпраці. Тому незважаючи на високі інвестиційні витрати необхідно поліпшення якісних показників діяльності портових підприємств. На підставі цього підходу формується висока ефективність господарювання завдяки розширенню масштабів діяльності порту.

Первинною формою взаємодії портових підприємств та припортової промисловості $є$ портовопромислова зона, яка включає: портові підприємства, підприємства, які взаємодіють з ними, і організації, що обслуговують їх інфраструктуру. До числа умов включення підприємств до складу портово-промислової зони відносять такі: основний обсяг поставок для них (сировина, комплектуючі, готова продукція та ін.) здійснюється через морський порт; контактна взаємодія з морським портом виступає в якості вирішального чинника локалізації підприємства у складі портово промислової зони. В системі портово-промислової зони можна виділити чотири основних види взаємодії :

виробничо-технологічна взаємодія, коли морський порт стає учасником технологічного процесу виробництва продукції;

матеріально-постачальна взаємодія, це взаємодія по лінії матеріально-технічного постачання підприємств;

складальна взаємодія, порт виступає центром тяжіння різноманітних коопераційних зв язків;

інвестиційна взаємодія, пов'язана 3 участю великих промислових підприємств в інвестиційному розвитку портів у формі акціонерного капіталу.

Еволюція основних форм транспортно-виробничо-наукової взаємодії підприємств у портової

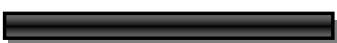

134
Економічні інновації

Випуск №63 
діяльності України пройшла наступні етапи:портово-промислова зона; портово-промисловий вузол; портово-промисловий комплекс; транспортно-виробниче об'єднання; морський кластер.

Створення мультимодального кластера дозволить вирішити наступні проблеми розвитку підприємств МГК України.

1. Спростити доступ до спеціалізованих факторів виробництва i робочій силі. Участь підприємства у морському кластері може забезпечити йому привілейований або більш дешевий доступ до таких специфічних факторів виробництва, як обладнання, бізнес-послуги, персонал у порівнянні з варіантами об'єднань по вертикалі, формальними альянсами і зовнішніми структурами або з імпортом факторів виробництва.

Мультимодальний кластер являє собою таку організаційну форму діяльності підприємств в портовій зоні, яка по своїй суті може бути більш ефективною у відношенні забезпечення факторами виробництва в разі доступності конкурентоспроможних місцевих постачальників.

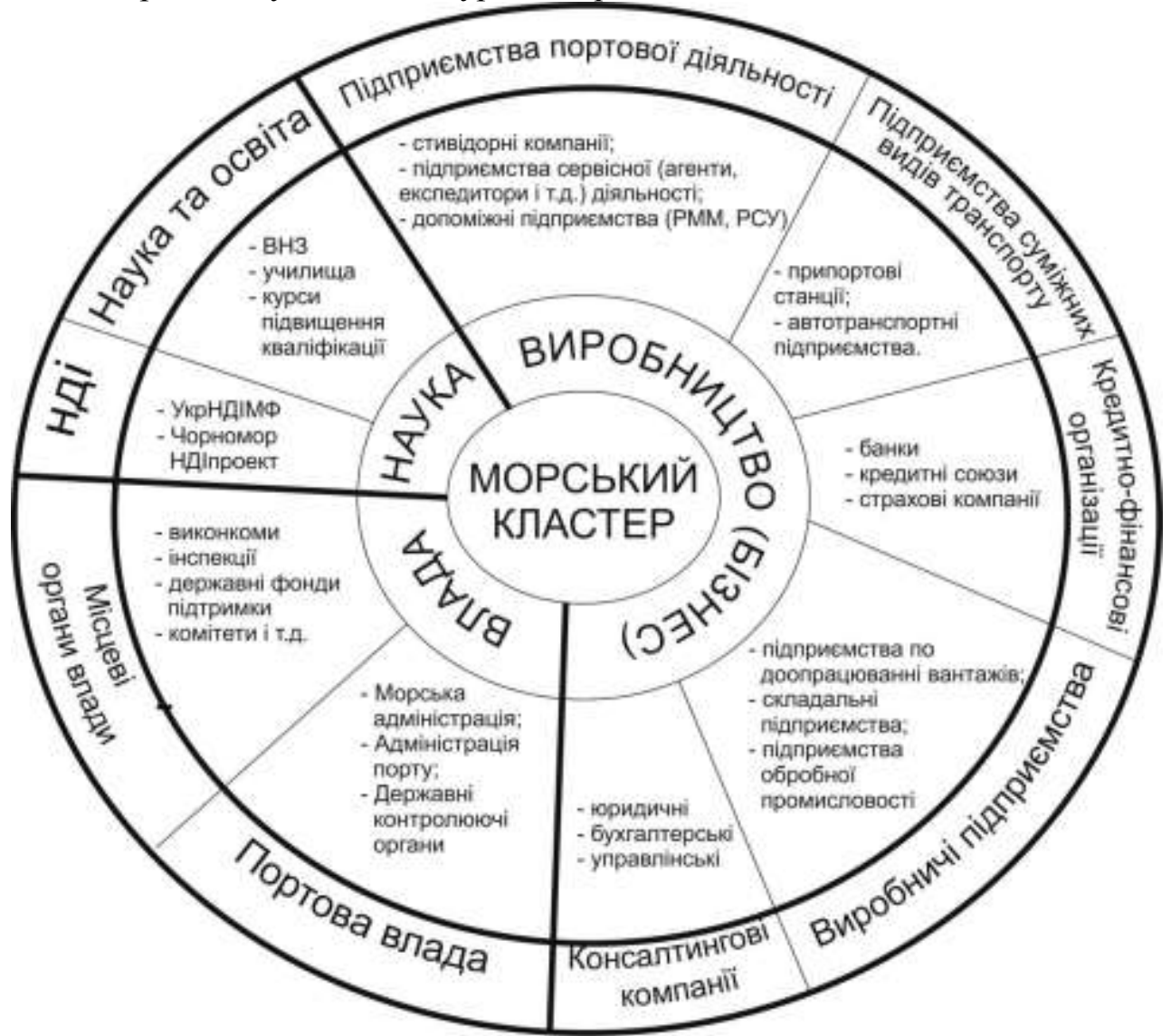

Рис. 1. Модель мультимодального кластера

Отримання ресурсів ззовні кластера може виявитися необхідним при недоступності конкурентоспроможних місцевих постачальників, але такій ситуації слід уникати, оптимізуючи структуру кластеру.

У той час як отримання факторів виробництва від учасників кластера (місцеві ресурси) може призводити до зниження собівартості робіт, ніж у випадку використання віддалених джерел (дистанційні ресурси). Доступність місцевих ресурсів мінімізує необхідність в матеріальновиробничих запасах і позбавляє від необхідності витрат на імпорт факторів виробництва, а також від пов'язаних з ним витрат

Відсутність конкурентоспроможних місцевих постачальників ресурсів знижує ефективність переваг мультимодального кластера, проте внутрішньо властиві кластерам переваги роблять сильний стимулюючий вплив на місцевих постачальників, які прагнуть бути більш досконалими і сильними, а вхідні в кластер підприємства прагнуть заохочувати появу нових постачальників, що стимулює розвиток конкуренції на даному ринку.

2. Поліпшити інформаційне забезпечення. Усередині мультимодального кластера може накопичуватися значний обсяг галузевих знань 3 менеджменту, маркетингу, технологій, а також інші

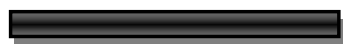

2017
Економічні інновації

Випуск №63 
спеціалізовані види інформації. Доступ до цієї інформації може бути краще організований і вимагати менших витрат для учасників мультимодального кластера, дозволяючи їм працювати за рахунок цього більш продуктивно і виходити на передовий рівень продуктивності. Подібна дія надає також і потік інформації між підрозділами одного підприємства. Близькість один до одного, зв'язку 3 технологій, а також наявність постійних особистих контактів і громадських зав'язків полегшують рух потоків інформації всередині мультимодального кластера. Важливим окремим випадком створюваних мультимодальним кластером інформаційних переваг $є$ доступність інформації про поточні потреби клієнтури, що найбільш актуально в світлі динамічного розвитку ринку транспортної продукції і послуг.

3. Удосконалити комплексність і взаємодоповнюваність. Мультимодальний кластер сприяє підвищенню ефективності роботи не тільки шляхом придбання факторів виробництва, а й тим, що він забезпечує розвиток взаємодоповнюваності між видами діяльності учасників морського кластера. У першу чергу це пов'язано з виробничою діяльністю. Наприклад, в стивідорної діяльності якість виконуваних робіт залежить не тільки від інтенсивності виконання ПРР, але також і від рівня існуючої інфраструктури порту, стану під'їзних шляхів, рівня сервісного обслуговування (агенти, експедитори, шипчандлери), можливості отримання додаткових послуг (інформаційне забезпечення) яких робіт (підробіток вантажів), взаємодії з суміжними видами транспорту.

3 цього прикладу видно, що складові ринку транспортних послуг часто виявляються сильно залежними один від одного. Незадовільна робота однієї його частини може негативно відбитися на результатах роботи інших. Ще одна форма взаємодоповнюваності в середині мультимодального кластера пов'язана 3 маркетингом. Присутність групи пов'язаних між собою підприємств і галузей в певному регіоні забезпечує ефективність спільного маркетингу (наприклад, рекомендації підприємства, спільні тематичні виставки, друковані видання та рекламні кампанії). Це може також підвищувати репутацію даного регіону в морській галузі, підвищуючи ймовірність того, що клієнти будуть віддавати перевагу розташованому там підприємству - виробнику продукції (робіт, послуг). Інші приклади взаємодоповнюваності всередині мультимодального кластера стосуються кращого впорядкування видів діяльності серед його учасників. Істотне підвищення ефективності роботи можливо тільки у випадку одночасних змін відразу у всіх частинах мультимодального кластера. Наприклад, важливим кроком, що дозволив провести зазначені зміни, може стати координація зусиль для вдосконалення системи ліцензування на транспорті. Подібні зв'язки можуть легше реалізовуватися в середині мультимодального кластера, ніж серед розрізнених учасників.

4. Оптимізувати організаційне забезпечення. За допомогою мультимодального кластера можна створювати такі фактори виробництва, які занадто дорогі для окремого учасника кластера. Підприємства зможуть отримувати доступ до таких вигод, як спеціалізована інфраструктура або поради експертів в місцевих інститутах при відносно низьких витратах.

5. Удосконалити систему аналізу і планування. Мультимодальний кластер може підвищити цінність стимулів всередині підприємств для досягнення більш високої продуктивності 3 кількох причин. По-перше, через конкурентного тиску. Суперництво з місцевими конкурентами надає особливо сильний стимулюючий вплив через легкість постійного порівняння результатів, а також через те, що місцеві суперники мають подібні загальні умови (вартість робочої сили, доступність фінансових і кредитних ресурсів і т.д.), у зв'язку з чим конкурентна боротьба повинна вестися в інших напрямках.

Мультимодальний кластер може сприяти розвитку системи аналізу різних напрямків діяльності підприємства, оскільки часто подібні функції виконують інші місцеві підприємства.

Менеджери отримають більш широкі можливості для порівняння результатів праці завдяки можливості порівняння ефективності праці своїх працівників 3 ефективністю праці в інших компаніях. Накопичення генеруються в мультимодальному кластері: наприклад, знання про галузеві фінансові інститути може, забезпечити прийняття рішень про позики та інших фінансових рішень на основі кращої інформованості, а також удосконалювати роботу з клієнтами. Також мультимодальний кластер може обмежити ймовірність здійснення некоректних дій, при яких, наприклад, один учасник отримує переваги за рахунок іншого або виробляє товари або послуги низької якості.

У зв'язку з постійним взаємодією, відносною легкістю поширення інформації, формування іміджу і бажанням зайняти гідне положення на ринку транспортної продукції і послуг учасники мультимодального кластера зазвичай прагнуть до конструктивної взаємодії, здатному надавати позитивний вплив на їх довгострокові інтереси.

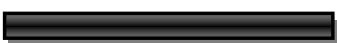

136
Економічні інновації

Випуск №63

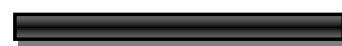

2017 
Таким чином, для підвищення рівня економічної стійкості мультимодального кластера в нього повинні залучатися характерні для даного регіону суспільні блага або вигоди, пов'язані з близькістю розташування компаній, особистими контактами, міцні й постійні зв'язками, а також з можливістю доступу до інформації " з середини ". Отримати доступ до переваг, пов'язаних з участю у діяльності мультимодального кластера, складно, а іноді й неможливо, якщо тільки підприємство не бере участі в цій діяльності, досить активно виявляючи помітну присутність у цьому регіоні.

Мультимодальний кластер заснований на ідеї вироблення дієвої співпраці між бізнесом, університетами та місцевою владою.

Об'єднання підприємств портової діяльності і пов'язаних 3 ними інших підприємств, організацій та установ у мультимодальний кластер сприятиме консолідації інтересів у суспільстві і виявить односпрямованість стратегічних інтересів переважної більшості учасників ринку портової продукції та послуг, сприятиме прозорості процесу прийняття управлінських рішень, що дасть можливість забезпечити передбачення економічної транспортної політики держави.

Необхідно ввести особливий режим економічного партнерства між органами влади, представниками бізнесу та науки 3 метою якнайшвидшого вирішення ключових питань у сфері соціально-економічної політики галузі (регіону), формувати реально здійснимі програми стратегічного розвитку транспортного комплексу України.

Мультимодальний кластер зможе об'єднати підприємства та організації для підвищення ефективності їх діяльності, зростання продуктивності праці та якості і зростання номенклатури надаваних послуг, стимулювання конкуренції та інновацій, залучення інвестицій. Мультимодальний кластер дозволить підприємствам та портам гнучко реагувати на зміну умов господарювання на ринку транспортних послуг.

Висновки та перспективи подальших досліджень. Розвиток форм взаємодії йде від найпростіших портово-промислових зон через їх об'єднання в портово-промислові вузли, що спираються на загальну інфраструктуру, до створення портово-промислових комплексів та формування транспортно-промислових комплексів, які представляють неформальне об'єднання транспортних і промислових підприємств, а також пов'язаних з ними організацій, розташованих на певній території і функціонуючих на принципах спільності інтересів та комплексності задоволення все зростаючих потреб учасників ринку транспортної продукції i послуг. Одночасно 3 організаційними формами розвивається функціональна взаємодія 3 таких видів як виробничотехнологічне, матеріально-постачальницькі, фінішно-складальне та інвестиційне. Наступним більш високим рівнем взаємодії підприємств, організацій та установ в системі портового комплексу має бути створення в морських регіонах країни мультимодальних кластерів, що передбачають залучення в сферу взаємодії навчальних закладів, науково-дослідних інститутів, банків, страхових та інших компаній, що дозволить створити атмосферу довіри між владою і бізнесом, поліпшити конкурентне середовище, забезпечити зростання продуктивності як промислових підприємств, так і портової діяльності і пов'язаними з нею видами діяльності.

\section{ЛІТЕРАТУРА}

1.Котлубай О.М. Теорія і методологія розвитку транспортно-технологічних систем перевезення вантажів/О.М. Котлубай.— Одеса: ІПРЕЕД НАН України, 2012.—200с.

2.Лимонов Э.Л. Внешнеторговые операции морского транспорта и мультимодальные перевозки/Э.Л. Лимонов.- СПб:Иформиацонный центр «Выбор»,2001.—416с.

3.Плужников К.И. Транспортное экспедирование /К.И. Плужников, Ю.А. Чунтомова.М.:ТРАНСЛИТ,2006.-528c.

4.Тарасенко В. Территориальные кластеры: Семь инструментов управления /В. Тарасенко .М.:Альпина Паблишер, 2015.-201с.

5.Крыжановский С.В. Морские торговые порты Украины в рыночных условиях/ С.В. Крыжановский.- Одесса:Астопринт,2008.—184c.

6.Войнаренко М.П. Концепція кластерів - шлях до відродження виробництва на регіональному рівні/ М.П. Войнаренко .— Економіст.—2000.—№1.—С.15-21.

7.Тараканов Н.Л.Региональные логистические системы: проблемы формирования и развития: монография / Н.Л.Тараканов.-Одесса: ИПРЭЭИ НАН Украины,2013.-312с.

8.Котлубай О.М.Основи економіки й організації сервісної діяльності в торговельному

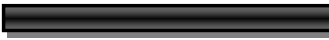

2017
Економічні інновації

Випуск №63 
мореплаванні/О.М. Котлубай, В.Г. Кухарчик .— Одеса: ІПРЕЕД НАН України, 2009.—197с.

9.Конкурентоспроможність та сталий розвиток морегосподарського комплексу України/[Ільченко С.В., Кухарчик В.Г. та інші];за ред.О.М. Котлубая.-Одеса: ІПРЕЕД НАН України, 2011.-427c.

10.Винников В.В. Проблемы комплексного развития морского транспорта/В.В.Винников.Одесса: ЧП «Феникс»,2005.-300с.

\section{REFERENCES}

1. Kotlubay OM (2012) Theory and methodology of the transport development and technological systems transport freight (Teoriya i metodologiya rozvitku transportno-tehnologichnih sistem perevezennya vantazhiv), Odessa: IPREED NAS of Ukraine [in Ukrainian].

2. Limonov E.L. (2001) Foreign trade operations of sea transport and multimodal transportations(Vneshnetorgovyie operatsii morskogo transporta i multimodalnyie perevozki), SPb: The ideological center "Choice" [in Russian].

3. Pluzhnikov K.I. (2006) Freight forwarding (Transportnoe ekspedirovanie), M.: TRANSLIT [in Russian].

4. Tarasenko V. (2015) Territorial clusters: Seven instruments of management (Territorialnyie klasteryi: Sem instrumentov upravleniya), M.: Alpina Pablisher [in Russian].

5. Kryzhanovskiy S.V. (2008) Sea trading ports of Ukraine in market conditions (Morskie torgovyie portyi Ukrainyi v ryinochnyih usloviyah), Odessa: Astoprint [in Russian].

6. Voinarenko M.P. (2000) Kontseptsiya klasteriv — shlyah do vIdrodzhennya virobnitstva na regionalnomu rivni [The concept of clusters is the way to the virginia vibrobitnva at the regional river] Ekonomist - Economist, 1, 15-21.[in Russian].

7. Tarakanov N.L.(2013)Regionalnye logistic systems: problems of formation and development: monograph(Regionalnyie logisticheskie sistemyi: problemyi formirovaniya i razvitiya: monografiya), Odessa: IPREED NAS of Ukraine [in Ukrainian].

8. Kotlubai O.M. (2009)The basis of economics and organisation of servicing in the merchant seaplane(Osnovi ekonomiki y organizatsiyi servisnoyi diyalnosti $\mathrm{v}$ torgovelnomu moreplavanni),Odessa: IPREED NAS of Ukraine [in Ukrainian].

9. Kotlubai OM (Eds.). (2011).Concurentosprodozhnnost that the steels rozvitok morgospodarsky to the complex of Ukraine.Odessa: IPREED NAS of Ukraine " [in Ukrainian].

10.Vinnikov V.V.(2015) Problems of complex development of sea transport (Problemyi kompleksnogo razvitiya morskogo transporta),Odessa: PE "Phoenix" [in Ukrainian].

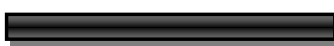

